\title{
Managing Resistance to Diamide Insecticides in Florida Tomato'
}

\author{
Hugh A. Smith ${ }^{2}$
}

Diamides belong to a class of insecticides that disrupt ryanodine receptors, the intracellular calcium channels that play a central role in muscle and nerve function. Diamide insecticides currently registered for use in Florida tomato production are chlorantraniliprole (e.g. Coragen), cyantraniliprole (Verimark, Exirel) and cyclaniliprole (Harvanta 50SL). Coragen can be applied via the soil or to the foliage. Verimark can only be applied as a tray drench or to the root zone. Exirel and Harvanta can only be applied to the foliage of the crop. Diamide insecticides have systemic properties and are effective against certain piercing-sucking, leafmining, and plant boring pests. They are taken up by the plant's vascular system and remain in the plant for a period of time, providing a longer residual effect than contact insecticides. Diamide insecticides have been assigned the mode of action classification number 28 by the Insecticide Resistance Action Committee (https:// irac-online.org/). The mode of action refers to the pathway or mechanism by which an insecticide kills. The IRAC mode of action number appears on the front of the label of any insecticide. Chlorantraniliprole and cyantraniliprole are available in additional formulations and in some products combined with other insecticides (Table 1).

Chlorantraniliprole, cyantraniliprole and cyclaniliprole are effective against the complex of caterpillars that attack Florida tomato (Table 2). They are also effective against the larvae of serpentine and vegetable leafminers (Liriomyza sativae Blanchardand L. trifolii Burgess), which can cause significant damage to tomato foliage. The key difference among diamides used in Florida tomato production is that cyantraniliprole (Verimark, Exirel) is effective against whitefly adults and nymphs and has been shown to reduce transmission of Tomato yellow leaf curl virus (TYLCV), whereas chlorantraniliprole (Coragen) and cyclaniliprole (Harvanta 50SL) have only a suppressive effect against whitefly populations. The most effective placement of Verimark in a tomato insecticide rotation may be at planting or within a few weeks of planting as protection against TYLCV, because the earlier the tomato crop is infected with the virus, the greater the impact on yield. However, leafminers and caterpillars do not tend to become problems in tomato until later vegetative and flowering stages of the crop. Optimal placement of Coragen or Harvanta 50SL to target caterpillars and leafminers in an insecticide rotation may be several weeks after planting, assuming the timing does not conflict with pollinator protection instructions on the insecticide label. Repeated applications of diamide insecticides throughout the crop cycle to address a complex of distinct pests that attack tomato at different phenological stages may result in successive generations of the pests being exposed to the same modes of action. This is how resistance to insecticides develops in pest populations.

In order to avoid the development of resistance to diamide insecticides in Florida tomato, growers should make strategic choices regarding the optimal placement of diamide insecticides in a season-long insecticide program.

1. This document is ENY-867, one of a series of the Entomology and Nematology Department, UF/IFAS Extension. Original publication date February 2013. Revised May 2021. Visit the EDIS website at https://edis.ifas.ufledu for the currently supported version of this publication.

2. Hugh A. Smith, associate professor, Entomology and Nematology Department; UF/IFAS Extension, Gainesville, FL 32611.

The Institute of Food and Agricultural Sciences (IFAS) is an Equal Opportunity Institution authorized to provide research, educational information and other services

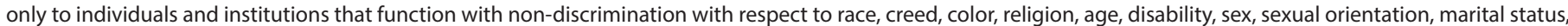

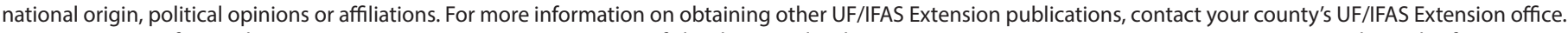
U.S. Department of Agriculture, UF/IFAS Extension Service, University of Florida, IFAS, Florida A \& M University Cooperative Extension Program, and Boards of County Commissioners Cooperating. Nick T. Place, dean for UF/IFAS Extension. 
Insecticide rotations can be designed around the treatment interval approach to avoid exposing successive generations of a pest to the same modes of action. In simplest terms, the treatment interval is the generation time of the pest being targeted and can be thought of as the number of days or weeks from birth to death in the typical life cycle of the pest. The development time of a pest is influenced by temperature and the host plant on which it develops. However, for planning purposes, fixed treatment intervals are used.

A five-week treatment interval is used to design insecticide rotations for whitefly management. This encompasses one week in the egg stage, two weeks in the nymphal stage, and an estimated two weeks alive as an adult.

The fundamental principal of the treatment interval approach is that insecticides with the same mode of action may be applied more than once in an interval if the label allows but cannot be applied at all in the following interval. The same modes of action can be applied more than once to a generation of a pest, but the following generation must be treated with completely different modes of action (or not treated at all) to avoid the development of resistance. Ideally, insecticides in a given mode of action group will only be applied during one treatment interval in a crop cycle. It should be kept in mind that once pests establish in a crop, overlapping generations develop, and it is impossible to completely avoid treating successive generations of a pest with the same modes of action. However, the treatment interval approach provides a useful framework for designing season-long insecticide rotations and offsetting the development of insecticide resistance.

In addition to the diamides, there are other mode of action groups available to manage whiteflies, caterpillars and leafminers in tomato (Table 3). These insecticides can be used as rotational partners with the diamides to design season-long programs for pest management in tomato. The most important insecticide group for managing whiteflies and TYLCV is group 4, which includes the neonicotinoid insecticides and one butenolide insecticide. Like diamides, group 4 insecticides are systemic. The neonicotinoids, mode of action group 4A, include imidacloprid (Admire Pro, many generics), thiamethoxam (Platinum) and dinotefuran (Venom, Scorpion). Flupyradifurone (Sivanto Prime) is a $4 \mathrm{D}$ insecticide. Group 4 insecticides are nicotinic acetylcholine agonists. Flupyradifurone is distinct from most neonicotinoid insecticides in that it has limited negative residual impacts on commercial pollinators when applied according to the guidelines described on the label.

The optimal placement of the group 4 insecticides, particularly dinotefuran and flupyradifurone, may be during the first five-week treatment interval when protection of the tomato crop against TYLCV is crucial (Figure 1). If group 4 insecticides are applied during the first five-week treatment interval, then the optimal placement of cyantraniliprole may be during the second five-week treatment interval, when in addition to providing protection against whiteflies and TYLCV, caterpillars and leafminers will also be controlled. Other insecticides that help manage whiteflies include the group 9 insecticides (afidopyropen, pymetrozine, pyrifluquinazon) and insecticides that reduce the survival of whitefly eggs and nymphs without impacting adults (buprofezin, pyriproxyfen, spirotetramat) (Table 3 ).

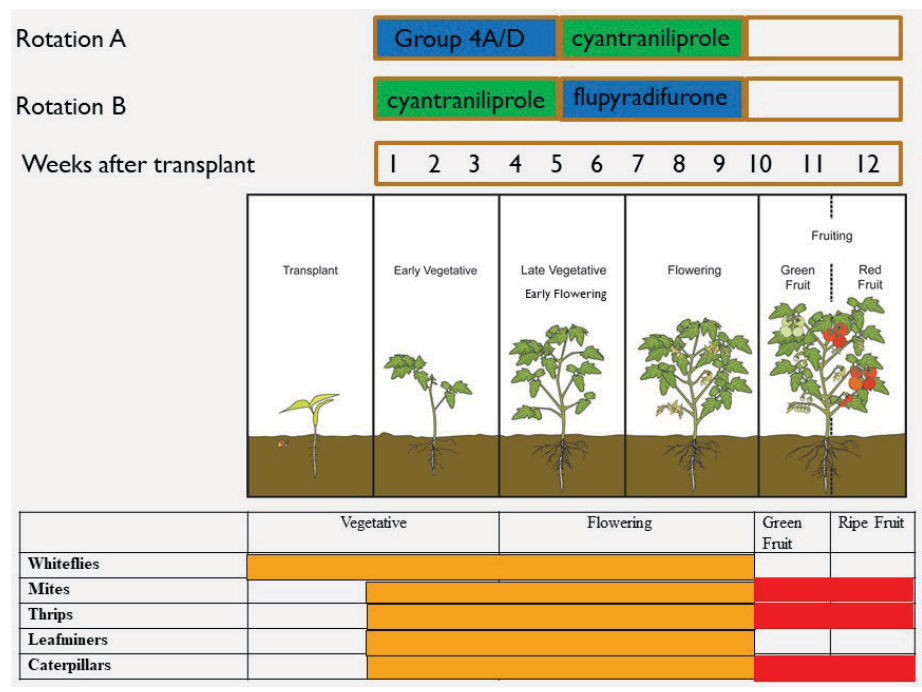

Figure 1. Key arthropod pests of tomato, the crop stages at which they are typically a problem, and two arrangements of group 4 insecticides and cyantraniliprole using a five-week treatment interval to manage whiteflies and Tomato yellow leaf curl virus.

If cyantraniliprole (Verimark and/or Exirel) is used during the first five-week treatment interval for early season management of whiteflies and TYLCV, flupyradifurone may be the best choice for continued whitefly control during the second five-week treatment interval because of its limited impact on pollinators that may appear as the crop enters its flowering stage. Unlike diamides, flupyradifurone and neonicotinoid insecticides will not help control caterpillars or leafminers. Abamectin (AgriMek, many generics; MOA \#6) and the molting disruptor cyromazine (Trigard, MOA \#17) are effective materials for managing leafminers in tomato. There are several additional insecticides representing distinct modes of action available to manage caterpillars, including Bacillus thuringiensis products (MOA \#11A), growth regulators (Confirm, Intrepid; MOA \#18), and the sodium channel modulator indoxacarb (Avaunt, MOA \#22). These materials should be used to manage caterpillars and leafminers during the second five-week treatment interval if cyantraniliprole or another diamide 
is used during the first five-week treatment interval for management of whiteflies and TYLCV.

In addition to the insecticides listed above, the group 5 insecticides can contribute to control of leafminers and thrips. These insecticides are marketed as Radiant SC (spinetoram) and Entrust (spinosad; approved for use in certified organic production). The group 5 insecticides are among the few materials that provide effective management of thrips in tomato, and they should not be used for leafminer or caterpillar management if problems with thrips are anticipated. The primary concern with thrips in tomato is that some species are vectors of Tomato spotted wilt virus (TSWV), Tomato chlorotic spot virus (TCSV) and Groundnut ringspot virus (GRSV). TSWV is a consistent problem in northeast Florida tomato production. TCSV and GRSV are well established in south Florida tomato production. Cyclaniliprole (Harvanta) provides suppression of western flower thrips (Frankliniella occidentalis). Cyantraniliprole (Verimark, Exirel) will provide suppression of foliar feeding thrips only; Verimark can help reduce transmission of TSWV if applied early in the crop cycle.

The treatment interval approach is one component of an overall strategy for managing pests in tomato and reducing the development of insecticide resistance. Other strategies should be incorporated to reduce reliance on insecticides, including planting tomato varieties with genetic tolerance to whitefly- and thrips-transmitted viruses, the use of metalized plastic mulches to repel whiteflies and thrips, and incorporation of biopesticides into insecticide rotations such as insecticidal soap which can reduce whitefly populations without selecting for insecticide resistance. The single most important thing Florida tomato growers can do to reduce losses to insects and the viruses they transmit is to promptly and thoroughly destroy harvested fields and fields that are no longer being managed due to environmental or economic factors. 
Table 1. Insecticides containing diamides available for management of pests of Florida tomato and other crops. This table lists registered insecticides that should be integrated with other pest management methods. Additional information on integrated pest management methods can be requested from UF/IFAS Extension horticulture or agriculture agents. A list of local UF/IFAS Extension county offices is available at https://sfyl.ifas.ufl.edu/find-your-local-office/.

\begin{tabular}{|l|l|l|}
\hline Product & MOA\# & Active ingredient(s) \\
\hline Coragen & 28 & chlorantraniliprole \\
\hline Besiege & $28+3 \mathrm{~A}$ & chlorantraniliprole + lambda cyhalothrin \\
\hline Durivo (soil) & $28+4 \mathrm{~A}$ & chlorantraniliprole + thiamethoxam \\
\hline Voliam Flexi (foliar) & $28+4 \mathrm{~A}$ & chlorantraniliprole + thiamethoxam \\
\hline Harvanta 50SL & 28 & cyclaniliprole \\
\hline Verimark (soil) & 28 & cyantraniliprole \\
\hline Exirel (foliar) & 28 & cyantraniliprole \\
\hline Minecto Pro & $28+6$ & cyantraniliprole + abamectin \\
\hline
\end{tabular}

Table 2. Rates, re-entry interval (REI), preharvest interval (PHI), and target pests for Coragen, Verimark, Exirel and Harvanta 50SL. This table lists registered insecticides that should be integrated with other pest management methods. Additional information on integrated pest management methods can be requested from UF/IFAS Extension horticulture or agriculture agents. A list of local UF/IFAS Extension county offices is available at https://sfyl.ifas.ufl.edu/find-your-local-office/.

\begin{tabular}{|c|c|c|}
\hline Insecticide & Target pests in Florida tomato & Restrictions \\
\hline $\begin{array}{l}\text { Coragen } \\
\text { (chlorantraniliprole) } \\
\text { Rates: } 3.5-7.5 \text { fl oz per acre (check label for } \\
\text { range by target pest and application method) } \\
\text { REl: } 4 \text { h } \\
\text { PHI: } 1 \text { day }\end{array}$ & $\begin{array}{l}\text { Beet armyworm, fall armyworm, loopers, } \\
\text { southern armyworm, tomato fruitworm, } \\
\text { tomato pinworm, leafminer larvae; } \\
\text { suppression of whitefly (Bemisia tabaci) } \\
\text { nymphs. }\end{array}$ & $\begin{array}{l}\text { Do not treat plants grown for transplanting. } \\
\text { Not for use in nurseries, plant propagation } \\
\text { houses, or greenhouses by commercial } \\
\text { transplant producers on plants being grown } \\
\text { for transplanting. } \\
\text { Application methods include in-furrow spray } \\
\text { at planting, transplant water treatment, } \\
\text { surface band at planting, or foliar. Label } \\
\text { contains pollinator protection instructions. }\end{array}$ \\
\hline $\begin{array}{l}\text { Verimark (cyantraniliprole) } \\
\text { Rate: } 5-13.5 \text { fl oz per acre (check label for } \\
\text { range by target pest and application method) } \\
\text { REI: } 4 \text { h } \\
\text { PHI: } 1 \text { day }\end{array}$ & $\begin{array}{l}\text { Beet armyworm, fall armyworm, southern } \\
\text { armyworm, tomato fruitworm, tomato } \\
\text { pinworm, leafminers (Liriomyza spp.) } \\
\text { whiteflies. }\end{array}$ & $\begin{array}{l}\text { Can be applied as a tray treatment drench } \\
\text { not more the } 72 \text { hours prior to transplanting. } \\
\text { Application methods include at-planting } \\
\text { as an in-furrow spray, transplant water } \\
\text { treatment, surface band. }\end{array}$ \\
\hline $\begin{array}{l}\text { Exirel } \\
\text { (cyantraniliprole) } \\
\text { 7-20.5 per acre (check label for range by } \\
\text { target pest and application method) } \\
\text { REI: } 12 \mathrm{~h} \\
\text { PHI: } 1 \text { day }\end{array}$ & $\begin{array}{l}\text { Beet armyworm, fall armyworm, southern } \\
\text { armyworm, tomato fruitworm, tomato } \\
\text { pinworm, tomato hornworm, loopers, } \\
\text { leafminers (Liriomyza spp.), whiteflies. }\end{array}$ & $\begin{array}{l}\text { Do not treat plants grown for transplanting. } \\
\text { Not for use in nurseries, plant propagation } \\
\text { houses, or greenhouses by commercial } \\
\text { transplant producers on plants being grown } \\
\text { for transplanting. Foliar application. Label } \\
\text { contains pollinator protection instructions. }\end{array}$ \\
\hline $\begin{array}{l}\text { Harvanta 50SL (cyclaniliprole) } \\
\text { Rate: } 10.9-16.4 \text { fl oz per acre } \\
\text { REI: } 4 \mathrm{~h} \\
\text { PHI: } 1 \text { day }\end{array}$ & $\begin{array}{l}\text { Beet armyworm, cabbage looper, fall } \\
\text { armyworm, southern armyworm, tomato } \\
\text { fruitworm, tomato hornworm, tomato } \\
\text { pinworm, yellowstriped armyworm, } \\
\text { leafminers (Liriomyza spp.) } \\
\text { Suppression of western flower thrips, } \\
\text { whiteflies, stink bug nymphs. }\end{array}$ & $\begin{array}{l}\text { Do not use in greenhouses. Foliar application } \\
\text { prohibited after onset of flowering until } \\
\text { flowering is completed unless it is made } \\
\text { between } 2 \text { hours prior to sunset until sunrise } \\
\text { or when temperature is } 50 \mathrm{~F} \text { or less. }\end{array}$ \\
\hline
\end{tabular}


Table 3. Insecticide groups organized by mode of action for management of whiteflies, caterpillars and leafminers in tomato. This table lists registered insecticides that should be integrated with other pest management methods. Additional information on integrated pest management methods can be requested from UF/IFAS Extension horticulture or agriculture agents. A list of local UF/IFAS Extension county offices is available at https://sfyl.ifas.ufl.edu/find-your-local-office/.

\begin{tabular}{|c|c|c|c|c|c|c|}
\hline MOA \# ${ }^{1}$ & Grouping or action site & Active ingredient examples & Examples & $\begin{array}{l}\text { Silverleaf } \\
\text { whitefly }\end{array}$ & Caterpillars & Leafminers \\
\hline $4 \mathrm{~A}$ & Neonicotinoid & $\begin{array}{l}\text { imidacloprid, thiamethoxam } \\
\text { dinotefuran, }\end{array}$ & $\begin{array}{l}\text { Admire Pro, } \\
\text { Platinum, Venom }\end{array}$ & $x$ & & \\
\hline 4D & Butenolide & flupyradifurone & Sivanto Prime & $x$ & & \\
\hline 5 & Spinosyns & spinosad, spinetoram & Entrust, Radiant & & $x$ & $x$ \\
\hline \multirow[t]{2}{*}{6} & \multirow[t]{2}{*}{ Avermectins } & abamectin & $\begin{array}{l}\text { AgriMek, many } \\
\text { generics }\end{array}$ & & & $x$ \\
\hline & & emamectin benzoate & Proclaim & & $x$ & \\
\hline $7 C$ & Juvenile hormone mimics & pyriproxifen & Knack & $\begin{array}{l}\text { whitefly eggs } \\
\text { and nymphs }\end{array}$ & & \\
\hline $9 B$ & \multirow{2}{*}{$\begin{array}{l}\text { Selective hemipteran } \\
\text { feeding blocker } \\
\text { (chordotonal modulators) }\end{array}$} & pymetrozine, pyrifluquinazon & Fulfill, PQZ & $x$ & & \\
\hline 9D & & afidopyropen & Sefina & $x$ & & \\
\hline $11 \mathrm{~A}$ & $\begin{array}{l}\text { Microbial disruptor of } \\
\text { insect midgut membrane }\end{array}$ & $\begin{array}{l}\text { Bacillus thuringiensis subspecies } \\
\text { aizawai; subspecies kurstaki }\end{array}$ & Xentari, Dipel & & $x$ & \\
\hline 16 & $\begin{array}{l}\text { Inhibitors of chitin } \\
\text { biosynthesis }\end{array}$ & buprofezin & Courier & $\begin{array}{l}\text { whitefly eggs } \\
\text { and nymphs }\end{array}$ & & \\
\hline 17 & Dipteran molting disruptor & cyromazine & Trigard & & & $x$ \\
\hline 18 & Ecdysone receptor agonist & tebufenozide, methoxyfenozide & Confirm, Intrepid & & $x$ & \\
\hline $21 \mathrm{~A}$ & METI insecticides & fenpyroximate & Portal & $x$ & & \\
\hline 22 & Sodium channel blocker & indoxacarb & Avaunt & & $x$ & \\
\hline 23 & Lipid biosynthesis inhibitor & spirotetramat & Movento & $\begin{array}{l}\text { whitefly eggs } \\
\text { and nymphs }\end{array}$ & & \\
\hline \multirow[t]{2}{*}{28} & \multirow[t]{2}{*}{$\begin{array}{l}\text { Ryanodine receptor } \\
\text { modulators }\end{array}$} & chlorantraniliprole, cyclaniliprole & $\begin{array}{l}\text { Coragen, } \\
\text { Harvanta 50SL }\end{array}$ & $\begin{array}{l}\text { suppression of } \\
\text { nymphs }\end{array}$ & $x$ & $x$ \\
\hline & & cyantraniliprole & Verimark, Exirel & $x$ & $x$ & $x$ \\
\hline - & unknown & azadirachtin & Azadirect & $x$ & $x$ & \\
\hline- & unknown & Beauveria bassiana & $\begin{array}{l}\text { BotaniGard, } \\
\text { Mycotrol - O }\end{array}$ & $x$ & & \\
\hline- & unknown & insecticidal soap & M-Pede & $x$ & & \\
\hline- & unknown & sylet oils & Suffoil-X & $x$ & & $x$ \\
\hline \multicolumn{7}{|c|}{$\begin{array}{l}{ }^{1} \text { Mode of Action (MOA) codes for plant pest insecticides from the Insecticide Resistance Action Committee (IRAC) Mode of Action Classification } \\
\text { v. } 8.2 \text { March 2017. Number codes ( } 1 \text { through } 29 \text { ) are used to distinguish the main insecticide mode of action groups, with additional letters for } \\
\text { certain sub-groups within each main group. All insecticides within the same group (with same number) indicate same mode of action. This } \\
\text { information must be considered for insecticide resistance management decisions. - = unknown, or a mode of action that has not been } \\
\text { classified yet. }\end{array}$} \\
\hline
\end{tabular}

